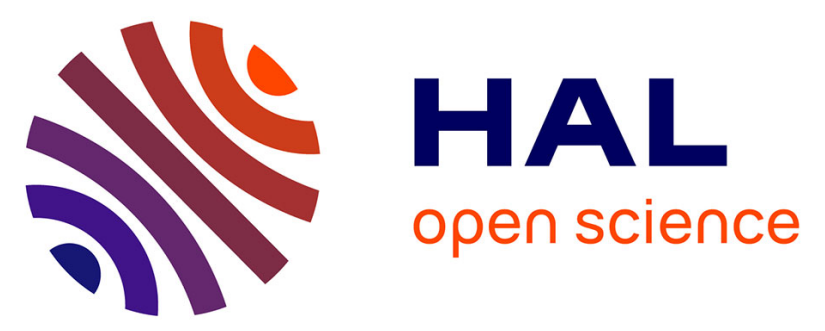

\title{
Firming of fruit tissues by vacuum infusion of pectin methylesterase: Visualisation of enzyme action
}

\author{
Anne A. Guillemin, Fabienne F. Guillon, Pascal P. Degreave, Corinne C. \\ Rondeau-Mouro, Marie Francoise M. F. Devaux, Francoise F. Huber, Eric \\ Badel, Rémi Saurel, Marc M. Lahaye
}

\section{To cite this version:}

Anne A. Guillemin, Fabienne F. Guillon, Pascal P. Degreave, Corinne C. Rondeau-Mouro, Marie Francoise M. F. Devaux, et al.. Firming of fruit tissues by vacuum infusion of pectin methylesterase: Visualisation of enzyme action. Food Chemistry, 2008, 109 (2), pp.368-378. 10.1016/j.foodchem.2007.12.050 . hal-00964569

\section{HAL Id: hal-00964569 \\ https://hal.science/hal-00964569}

Submitted on 18 Feb 2019

HAL is a multi-disciplinary open access archive for the deposit and dissemination of scientific research documents, whether they are published or not. The documents may come from teaching and research institutions in France or abroad, or from public or private research centers.
L'archive ouverte pluridisciplinaire HAL, est destinée au dépôt et à la diffusion de documents scientifiques de niveau recherche, publiés ou non, émanant des établissements d'enseignement et de recherche français ou étrangers, des laboratoires publics ou privés. 



\title{
Firming of fruit tissues by vacuum-infusion of pectin methylesterase: Visualisation of enzyme action
}

\author{
Anne Guillemin $^{\mathrm{a}}$, Fabienne Guillon ${ }^{\mathrm{b}}$, Pascal Degraeve ${ }^{\mathrm{a}, *}$, Corinne Rondeau ${ }^{\mathrm{b}}$, \\ Marie-Françoise Devaux ${ }^{\mathrm{b}}$, Françoise Huber ${ }^{\mathrm{c}}$, Eric Badel $^{\mathrm{c}}$, Rémi Saurel ${ }^{\mathrm{d}}$, Marc Lahaye ${ }^{\mathrm{b}}$ \\ ${ }^{a}$ Université Lyon 1, Laboratoire de Recherche en Génie Industriel Alimentaire (EA 3733), IUT A - Département de Génie Biologique, \\ Technopole Alimentec - rue Henri de Boissieu, 01060 Bourg en Bresse Cedex 9, France \\ ${ }^{\mathrm{b}}$ UR1268 Biopolymères Interactions Assemblages, INRA, 44300 Nantes, France \\ ${ }^{c}$ Laboratoire d'Etudes et de Recherches sur le Matériau Bois, UMR 1093 INRA-AgroParisTech-Université Nancy I, 54042 Nancy, France \\ ${ }^{\mathrm{d}}$ Université de Bourgogne, Equipe Eau-Molécules actives - Macromolécules-Activités (EA 581), ENSBANA, 1 Esplanade Erasme, 21000 Dijon, France
}

Received 6 September 2007; received in revised form 29 October 2007; accepted 17 December 2007

\begin{abstract}
Apple pieces were vacuum-impregnated with either a pectin methylesterase (PME) and calcium solution or with water prior to pasteurization. Pasteurized apple pieces impregnated with PME and calcium showed a significantly higher firmness. Moreover, solid state ${ }^{13} \mathrm{C}$ NMR spectroscopy of apple cell wall residues revealed an increase of their molecular rigidity. Exogenous PME addition involved a decrease from $82 \%$ to $45 \%$ of apple pectin degree of methyl-esterification. Microscopic observations of apple slices immunolabelled with antibodies specific for pectins showed that (i) demethyl-esterification was more intense in the cell wall region lining intercellular spaces (demonstrating a key role for these intercellular channels in the enzyme penetration in the tissue during vacuum-infusion) and that (ii) the number of calcium-dimerized deesterified homogalacturonan chains increased. The results corroborate the hypothesis that vacuumimpregnated PME action liberates free carboxyl groups along pectin chains that could interact with calcium, increasing the rigidity of pectins and finally the mechanical rigidity of apple tissue.
\end{abstract}

(C) 2007 Elsevier Ltd. All rights reserved.

Keywords: Vacuum-impregnation; Fruit firmness; Pectin; Pectin methylesterase

\section{Introduction}

Texture is a major quality attribute of fruits and vegetables. It is generally markedly affected during preservation by thermal processes, such as freezing, blanching, pasteurization or sterilization. These processes lead to irreversible damage of cellular tissue, resulting in softening. Fruit and vegetable texture attributes rely, importantly, on cell wall structure (Kunzek, Habbert, \& Gloyna, 1999). Most of these walls are rich in pectin (Voragen, Pilnik, Thibault, Axelos, \& Renard, 1995), which consists of a complex family of acidic polysaccharides built on several structural domains (Ridley,

\footnotetext{
* Corresponding author. Tel.: +33 (0)474455252; fax: +33 (0)474455253. E-mail address: degraeve@iutbourg.uni-lyon1.fr (P. Degraeve).
}

O’Neil, \& Mohnen, 2001). Among these, partially methylesterified homogalacturonans in the middle lamella play an important role in cell adhesion with an impact on texture (Jarvis, Briggs, \& Knox, 2003). Hydrolysis of methyl esters on pectin by endogenous or plant pathogens pectin methylesterases (PME, EC 3.1.1.11) promotes calcium-mediated homogalacturonan interactions, contributing to cell wall mechanical properties and to fruit firmness (Jarvis et al., 2003). 'Vacuum-infusion' or 'vacuum-impregnation' (VI) of firming agents such as hydrocolloids (starch, pectin, alginate, gelatin) has been developed in order to reduce the softening caused by hydrothermal processing (Matringe, Chatellier, \& Saurel, 1999). Vacuum-infusion technology is based on hydrodynamic mass transfers promoted by pressure changes. The food products are bathed in an 
impregnation solution under vacuum before restoring the atmospheric pressure (Fito, Andres, Chiralt, \& Pardo, 1996; Fito and Pastor, 1994). On pressure release, the occluded gas in the pores of fruit and vegetable tissues is exchanged by the impregnation solution in a quick and simple way (Saurel, 2004). Recently, solutions containing pectin methylesterase and calcium have been vacuum-infiltrated. This resulted in the preservation of firmness in processed fruits and vegetables (Banjongsinsiri, Kenney, \& Wicker, 2004a; Degraeve, Saurel, \& Coutel, 2003; Javeri, Toledo, \& Wicker, 1991; Suutarinen, Honkapää, Heiniö, Autio, \& Mokkila, 2000).

In order to better understand the firming mechanism resulting from the vacuum-impregnation of pectin methylesterase, Guillemin, Degraeve, Guillon, Lahaye and Saurel (2006) followed the infiltration of the enzyme in apple cubes. The enzyme was deeper and more homogeneously distributed in apple cubes after the process than by simple soaking. The thermally treated apple cubes were also firmer than the controls. To follow up on this work, we now report on the impact of the infiltrated enzyme on the chemistry of homogalacturonan in apple tissue. We hypothesize that the enzymatic demethyl-esterification of pectins, combined with the increased concentration of calcium resulting from the infiltration process, will contribute to create new pectin ionic bonds, resulting in the strengthening of the tissue.

\section{Materials and methods}

\subsection{Raw material and vacuum-impregnation solution preparation}

Granny Smith apples (France) grown in 2005 were purchased from a local grocer. Apples were stored at $4{ }^{\circ} \mathrm{C}$ and processed within two weeks to minimize development of chilling injury. The fruits were peeled, hollowed out, and manually cut into $1.5 \mathrm{~cm}$ cubes with a sharp stainless steel blade or into slices (diameter $2 \mathrm{~cm}$ and thickness $8 \mathrm{~mm}$ ).

Impregnation solutions were prepared with predetermined quantities of calcium chloride $\left(0.5 \%\right.$ w/w $\mathrm{CaCl}_{2}$, $2 \mathrm{H}_{2} \mathrm{O}$ ) and Aspergillus niger PME preparation (Rapidase ${ }^{\circledR}$ FP Super, DSM Food Specialties, Seclin, France) $(3 \%)$ $\left(450 \mathrm{nkat}^{-1}\right.$ at $\mathrm{pH} 4.5$ and $30^{\circ} \mathrm{C}$ ). Milli Q water (Millipore, Bedford, MA, USA) was used throughout the study. All chemicals were of analytical grade.

Polyclonal rabbit antiserum raised against purified $A$. niger PME was obtained by multiple intradermic injections into rabbits. Experiments on animals were carried out in an approved institutional laboratory (Etablissement Français du Sang, Nantes, France) in accordance with national standards. Antigen-antibody reactivity and specificity were checked by standard enzyme-linked immunosorbent assay (ELISA) titration using non-immune rabbit control sera. Competitive ELISA allowed checking that plant PME did not cross-react with anti- $A$. niger PME antibodies.

The antibodies used to characterize the pectic chain in this study were the rat monoclonal antibody JIM7 (Clau- sen, Willats, \& Knox, 2003) and the mouse monoclonal antibody 2F4 (Liners, Letesson, Didembourg, \& Van Cutsem, 1989; Liners, Thibault, \& Van Cutsem, 1992).

\subsection{Apple cubes treatment}

\subsubsection{Vacuum-impregnation treatment}

Eighty grammes, corresponding to about 30 apple cubes or apple slices, were put in a 11 vessel at ambient temperature and covered with a stainless steel mesh to maintain the samples in the solution. The vessel was subsequently placed in the vacuum-impregnation chamber and held under vacuum (0.05 bar unless otherwise stated) for 2 min before admitting, by depression, $500 \mathrm{~g}$ of impregnation solution into the vessel (during about $10 \mathrm{~s}$ ). After a contact of $20 \mathrm{~s}$, the vacuum was released within $10 \mathrm{~s}$. Thus, the fruit material was held under vacuum for less than $2.5 \mathrm{~min}$. Then, it was maintained immersed for $5 \mathrm{~min}$ at atmospheric pressure. Vacuum-impregnated fruit material was subsequently drained, weighed, submitted immediately to thermal activation and/or pasteurization (see Section 2.2) before microscopic observations, tests of firmness or analytical determinations (unless otherwise stated).

\subsubsection{Exogenous PME activation and apple slices pasteurization}

A. niger PME activation consisted in incubating apple slices $(100 \mathrm{~g})$ in $10 \%(\mathrm{w} / \mathrm{w})$ sucrose solution $(500 \mathrm{ml})$ at $40{ }^{\circ} \mathrm{C}$ for $20 \mathrm{~min}$. These temperature and time conditions correspond to optimal conditions for enzyme activity. Enzyme inactivation and apple slices pasteurization were achieved by incubation at $85^{\circ} \mathrm{C}$ for $15 \mathrm{~min}$.

\section{3. $p H$}

$\mathrm{pH}$ was measured by taking five replicate readings in apple puree with a $\mathrm{pH}$ meter (Tacussel Electronic, Marseille, France).

\subsection{Firmness of fruits}

Firmness of apple slices, after activation and pasteurization phases, was evaluated by measuring the compression force with a Texture Analyzer (TA-XT2, Stable Microsystems, Godalming, England) using a $250 \mathrm{~N}$ load cell. The compression rate was performed at a constant speed of $1 \mathrm{~mm} \mathrm{~s}^{-1}$ until sample was crushed. The Young's modulus was evaluated using the slope of the linear elastic part of the force-displacement curve. Each measurement was replicated 20 times.

\subsection{Analytical methods}

Cell walls were prepared from about $100 \mathrm{~g}$ of fresh or treated apple cubes and isolated as alcohol-insoluble material. The apple cubes were cut into small pieces and immersed in $300 \mathrm{ml}$ of $96 \%$ (v/v) boiling ethanol for 
$20 \mathrm{~min}$ in order to inactivate endogenous enzymes. Then the samples were washed in $70 \%(\mathrm{v} / \mathrm{v})$ ethanol $(200 \mathrm{ml})$ until the filtrate was sugar-free (phenol/sulphuric acid test). The alcohol-insoluble material was dried by solvent exchange $(96 \%$ (v/v) ethanol and acetone), air-dried overnight at room temperature, and vacuum-dried for $24 \mathrm{~h}$ at $40{ }^{\circ} \mathrm{C}$.

Alcohol-insoluble material was submitted to a $30 \mathrm{~min}$ prehydrolysis with $72 \% \mathrm{H}_{2} \mathrm{SO}_{4}$ at $30^{\circ} \mathrm{C}$, followed by a $2 \mathrm{~h}$ hydrolysis with $2 \mathrm{~N} \mathrm{H}_{2} \mathrm{SO}_{4}$ at $100{ }^{\circ} \mathrm{C}$. Then, the sample was centrifuged for $10 \mathrm{~min}$ at $24,000 \mathrm{~g}$ at $4{ }^{\circ} \mathrm{C}$. The supernatant was collected and uronic acids were determined by colorimetry (Blumenkrantz and Asboe-Hansen, 1973; Thibault, 1979).

The methylation degree (mol methanol for $100 \mathrm{~mol}$ uronic acid) of apple pectin was determined on alcoholinsoluble material by saponification and reversed phase high performance liquid chromatography (RP-HPLC) separation on a C18 column according to Levigne et al. (2002).

\subsection{Microscopy}

\subsubsection{Environmental scanning electron microscopy (ESEM)}

Microscopic observations were performed just after vacuum-infusion, activation of PME and pasteurization of apple cubes. The control and treated cubes were cut longitudinally in halves with a razor blade, and the freshly cut faces were directly observed with an ESEM microscope (FEI Company, Quanta 200, Nancy, France) without another preparation. A LFD (low vacuum secondary electron detector) captor was used to limit the drying of the samples.

\subsubsection{Sample preparation for light and transmission electron microscopy}

Immediately after vacuum-impregnation and PME activation, the apple cubes were sliced with a razor blade in three concentric zones from the surface to the centre as described by Guillemin et al. (2006). The superficial, intermediate and core zones corresponded to the layer between the surface and $2 \mathrm{~mm}$ depth in the cubes, 2 and $4 \mathrm{~mm}$ depth in the cubes and the centre of the cubes, respectively.

Slices of each apple cube zone $\left(1 \mathrm{~mm}^{3}\right)$ were sampled from the different treated apple cubes. The samples were fixed in a mixture of $3 \%(\mathrm{w} / \mathrm{v})$ paraformaldehyde and $1 \%$ (w/v) glutaraldehyde in a $0.1 \mathrm{M}$ sodium phosphate buffer $(\mathrm{pH} 7.4)$ for $4 \mathrm{~h}$ at $4{ }^{\circ} \mathrm{C}$. Samples were washed with the same buffer, followed by rinsing with deionised water. Then, they were dehydrated in a graded aqueous ethanol series. Dehydrated cubes were progressively infiltrated with a London Resin White (LRW) acrylic resin and then embedded in gelatin capsules. The resin was polymerised for 4 days at $55^{\circ} \mathrm{C}$ without accelerator (Guillemin et al., 2005).

Semi-thin sections ( $1 \mu \mathrm{m}$ thick) were prepared and mounted on multiwell glass sides pretreated with VectaBond $^{\mathrm{TM}}$ section adhesive (British BioCell International,
UK). Ultrathin sections for electron microscopy were collected on carbon coated nickel grids.

\subsubsection{Immunolabelling of PME and pectin epitopes}

Prior to incubation with JIM7 or anti-A. niger PME antibodies, sections of apple cubes were blocked with $0.1 \mathrm{M}$ phosphate buffered saline ( $\mathrm{pH}$ 7.2) (PBS) containing $3 \%(\mathrm{w} / \mathrm{v})$ skimmed milk (PBS/SM) for $20 \mathrm{~min}$ at room temperature. Antibodies were applied to the section for $1 \mathrm{~h}$ at room temperature. JIM7 was diluted 1:10 (v:v) in PBS/SM while anti- $A$. niger PME antibodies were diluted 1:20 (v:v) in the same buffer. The sections were then washed with several changes in an excess of the PBS/SM buffer and incubated for $1 \mathrm{~h}$ at room temperature with the secondary antibody (anti-rat or anti-rabbit IgG according to the animal species from which the primary antibodies were raised) marked with Alexa-Fluor 546 diluted 1:100 (v:v) or gold particles for light or electron microscopy, respectively. Sections were washed in PBS/SM buffer and then rinsed twice in distilled water.

Sections to be incubated with $2 \mathrm{~F} 4$ were blocked with $3 \%$ $(\mathrm{w} / \mathrm{v})$ bovine serum albumin (BSA) in $20 \mathrm{mM}$ Tris- $\mathrm{HCl}$, pH 8.2, $0.5 \mathrm{mM} \mathrm{CaCl}_{2}, 150 \mathrm{mM} \mathrm{NaCl}$ (TCaS buffer) for $1 \mathrm{~h}$ at room temperature. Antibodies were applied to the section for $2 \mathrm{~h}$ at room temperature. $2 \mathrm{~F} 4$ serum was diluted $1: 50(\mathrm{v}: \mathrm{v})$ in $0.3 \%$ BSA $(\mathrm{w} / \mathrm{v})$ TCaS buffer. The sections were then washed with several changes in an excess of the $0.3 \%$ BSA TCaS buffer and incubated for $1 \mathrm{~h}$ at room temperature with the secondary antibody marker conjugate (anti-mouse IgG with $1 \mathrm{~nm}$ colloidal gold complexes, Aurion, Netherlands), diluted 1:20 (v:v) in the 0.3\% BSA TCaS buffer.

For light microscopy, sections were examined on a LEICA DMRD microscope equipped with epifluorescence irradiation (light microscopy LM). A band pass filter, 515$560 \mathrm{~nm}$, was used as excitation filter and fluorescence detected above $570 \mathrm{~nm}$. Images were acquired using a CCD camera (ATX 200L Photometrix, Australia).

For electron microscopy, the average gold particle size was increased by silver enhancement as recommended by the manufacturer (Aurion R-GENT SE-EM, Wageningen, Netherlands). After washing, the grids were stained with $4 \%(\mathrm{w} / \mathrm{v})$ uranyl acetate. Sections were examined with a JEOL $100 \mathrm{~S}$ with an accelerating voltage of $80 \mathrm{kV}$.

\subsubsection{Image analysis}

Bright field and immunofluorescence images of the same scene were systematically acquired. Image analysis was first applied on bright field image to segment the cell walls. The uneven illumination in the bright field image was corrected using a top-hat filter. A threshold value of 75 was visually chosen, leading to segmentation of the cells. The cell wall binary image was used as a binary mask for collecting the fluorescence of the cell wall in the fluorescence image. For each scene, the average fluorescence intensity was calculated as the total fluorescence intensity observed in the fluorescent image divided by the surface of the segmented 
cell walls in the bright field image. The procedure was developed in the Matlab environment (TheMathWorks, USA, http://wwwmathworks.com).

\subsection{NMR spectroscopy}

Cross-polarisation (CP) magic angle spinning (MAS) NMR spectra were acquired on a Bruker-DMX 400 spectrometer operating at a ${ }^{13} \mathrm{C}$ frequency of $100.62 \mathrm{MHz}$. The MAS rate was fixed at $7000 \mathrm{~Hz}$ and each experiment was recorded at ambient temperature $\left(20.85 \pm 1{ }^{\circ} \mathrm{C}\right)$.

The cross-polarisation experiments were carried out using a $90^{\circ}$ proton pulse of $5 \mu \mathrm{s}$, a $1 \mathrm{~ms}$ contact time at $50 \mathrm{kHz}$ and an acquisition time of $17 \mathrm{~ms}$ during which dipolar decoupling (tppm) of $50 \mathrm{kHz}$ was applied. 10,000 scans were acquired for each spectrum with a recycle time of $2 \mathrm{~s}$. Chemical shifts were determined by using the carbonyl peak of glycine as external reference. Samples were rehydrated to $80 \%(\mathrm{w} / \mathrm{w})$ for at least $3 \mathrm{~h}$ prior to NMR analysis.

\section{Results and discussion}

\subsection{Vacuum-impregnation of $P M E$ and calcium results in} better conserved apple tissue microstructure and firmness on pasteurization and increases macromolecular rigidity of cell walls

The impact of the vacuum-infiltration of PME and calcium on apple tissue microstructure and firmness was assessed by environmental scanning electron microscopy (ESEM) and texture analysis (mechanical resistance to compression measurement). Pasteurization of untreated control apple cubes led to shrinkage of the tissue, reduction of the intercellular spaces and folding of cell walls (Fig. 1). However, the same hydrothermal treatment applied to vacuum-impregnated with PME and calcium samples did not markedly alter their microstructure. Tissue and cell wall structures appear like fresh apple tissue (Fig. 1; Nieto,
Salvatori, Castro, \& Almazora, 2004). This preserved structure was associated with a significantly higher Young's modulus for pasteurized apple cubes vacuumimpregnated with PME and calcium than for controls ( $p<0.05$; Fig. 2). The higher mechanical rigidity of apple cubes infiltrated with PME and calcium agrees with previous reports on the firming effect of this process on canned peaches (Javeri et al., 1991) and pasteurized strawberries (Degraeve et al., 2003). This firming of tissue associated with the PME and calcium infiltration is attributed to the combined effect of the methyl ester groups hydrolysis on pectin and the interaction of the free carboxylic acid groups thus liberated with calcium (Grant, Morris, Rees, Smith, \& Thom, 1973; Saurel, 2004).

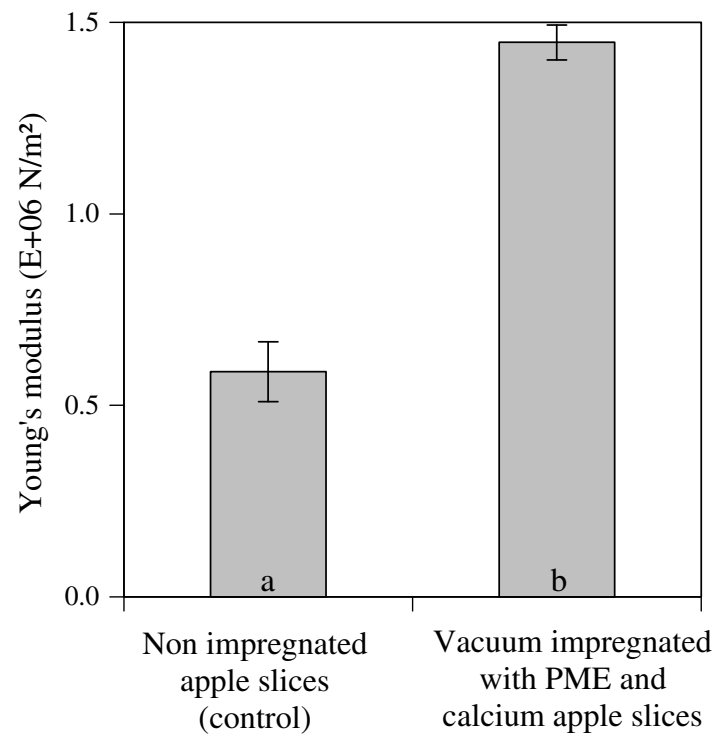

Fig. 2. Young's modulus obtained by a compression test of apple slices ( $2 \mathrm{~cm}$ diameter and $0.8 \mathrm{~cm}$ height) after vacuum-impregnation with PME (90 nkat $\mathrm{g}^{-1}$ ) and calcium $\left(0.5 \%\right.$ (w/w) $\mathrm{CaCl}_{2}, 2 \mathrm{H}_{2} \mathrm{O}$ solution) (a) or no treatment (control) (b). The test was performed after the slices were maintained at $40^{\circ} \mathrm{C}$ for $20 \mathrm{~min}$ and then pasteurized. Errors bars correspond to standard deviation $(n=20)$.
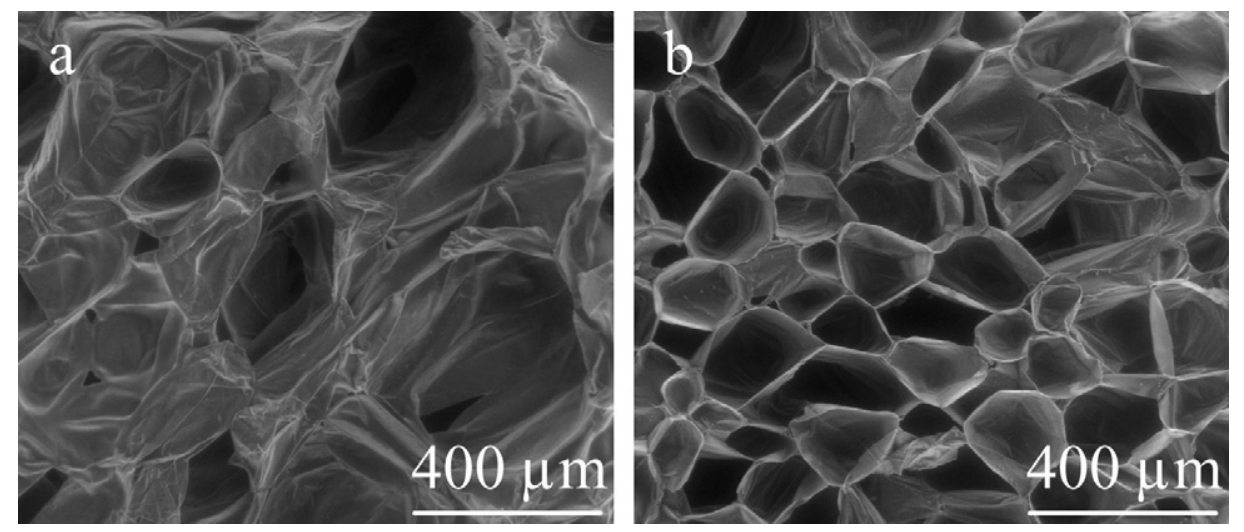

Fig. 1. ESEM micrographs of parenchyma tissue of apple (core of apple cubes). After vacuum-impregnation with PME (450 nkat $\mathrm{g}^{-1}$ ) and calcium ( $1 \%$ (w/w) $\mathrm{CaCl}_{2}, 2 \mathrm{H}_{2} \mathrm{O}$ solution), followed by incubation for $20 \mathrm{~min}$ at $40{ }^{\circ} \mathrm{C}$ (a) or no treatment (control) (b). Impregnated and control samples are heated at $85^{\circ} \mathrm{C}$ for $15 \mathrm{~min}$. 
The impact of PME and calcium infiltration in apple cube was also assessed by solid state ${ }^{13} \mathrm{C}$ NMR spectroscopy of the alcohol-insoluble material. CPMAS (crosspolarisation magic angle spinning) NMR spectra are shown in Fig. 3B and A, respectively. They were characteristic of cell wall residues containing cellulose (C1-C6 signals) and pectins (P1-P6). Larger signals were observed for the vacuum-impregnated samples (Fig. 3A), resulting in a lower spectral resolution compared to the non-impregnated samples (Fig. 3B). Since the spectra have been acquired under the same conditions, this observation is directly related to a higher anisotropy for tissues vacuumimpregnated with PME and calcium. Anisotropy observed by NMR increases with disorder (for crystallised samples) and/or molecular rigidity. The lower NMR resolution in the case of the enzyme infiltrated apple tissues (Fig. 3A) is attributed to an increase in the molecular rigidity of cell wall polysaccharides.
3.2. The infiltrated enzyme is active in situ and leads to an increase in non-esterified homogalacturonan blocks

The location of exogenous PME in sections of vacuuminfiltrated apple tissue was previously shown to be homogeneously distributed in all the sections and close to the cell walls (Guillemin et al., 2006). Immunolabelling of processed apple cubes with anti- $A$. niger PME antibodies confirmed this result (Fig. 4). The enzyme was equally distributed, whatever the depth in the sample cubes as quantified by fluorescence intensity (Fig. 5).

In order to check the activity of the infiltrated enzyme on pectin, the degree of methyl-esterification of pectins was measured and methyl-esterified and non-esterified pectin epitopes were visualized in the cell walls in processed and control samples using specific monoclonal antibodies.

The degrees of methyl-esterification of pectin in apple cubes vacuum-infiltrated with water or PME and

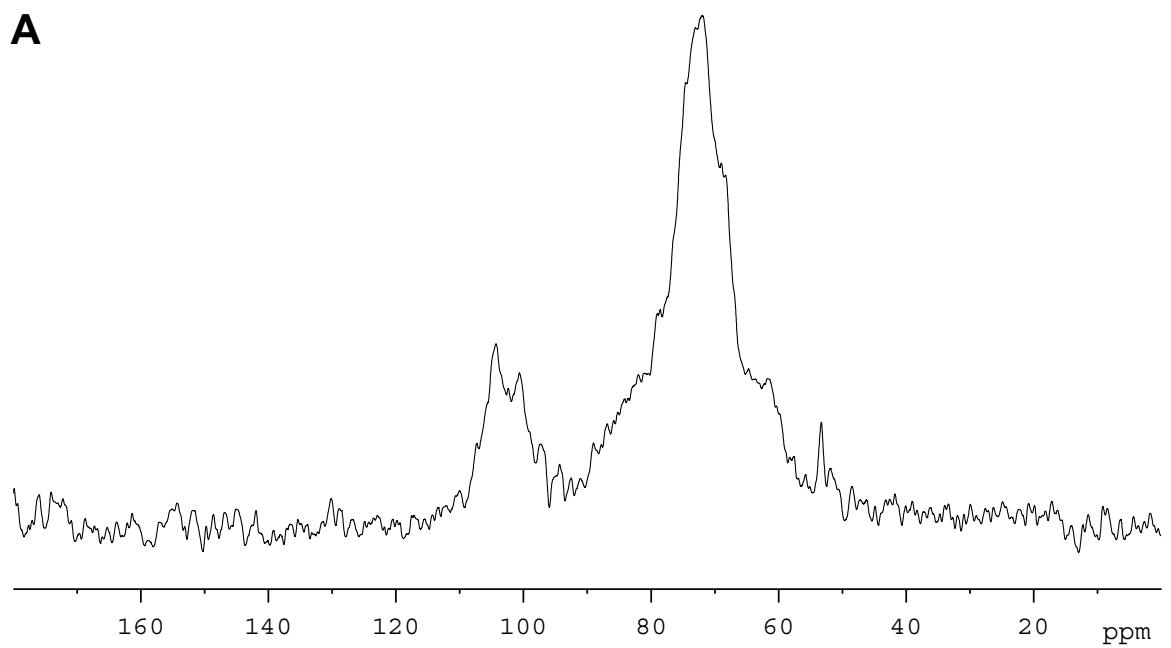

B

$\mathbf{C 2 , 3 , 5}$

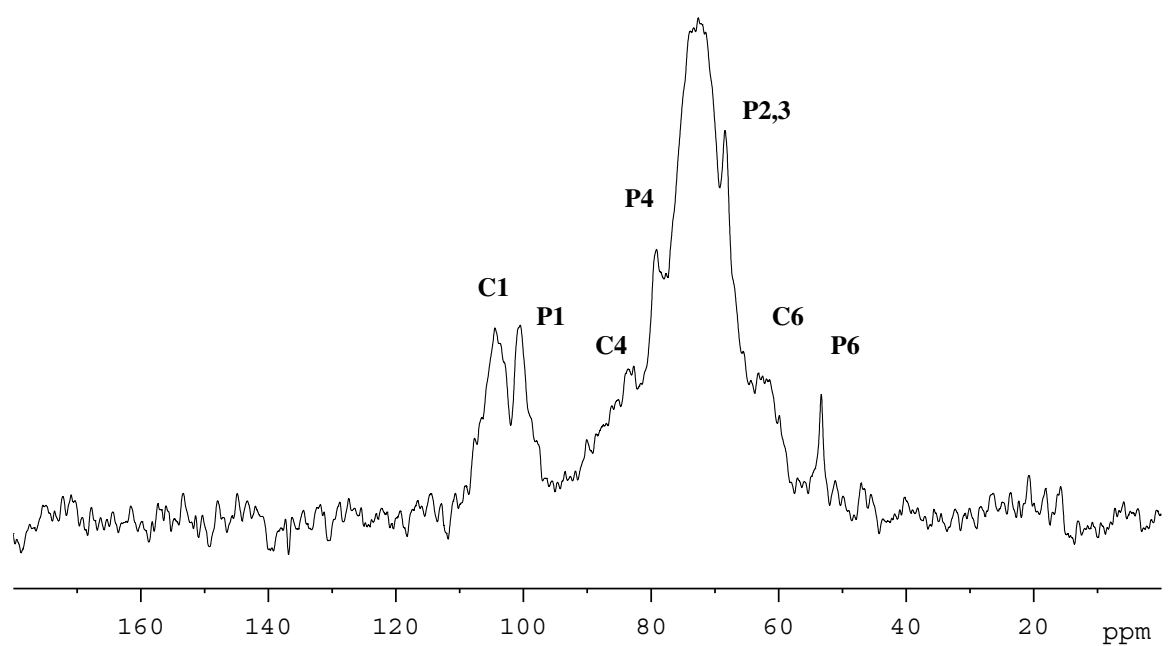

Fig. 3. Carbon CPMAS spectra of re-hydrated alcohol-insoluble residue (AIR) from apple tissues non-impregnated (B) and vacuum-impregnated with PME and calcium, maintained at $40^{\circ} \mathrm{C}$ for $20 \mathrm{~min}$ and then pasteurized (A). C1-C6 correspond to signals attributed to cellulose, P1-P6 to signals attributed to pectins (P6 being the carbon of the methyl ester). 

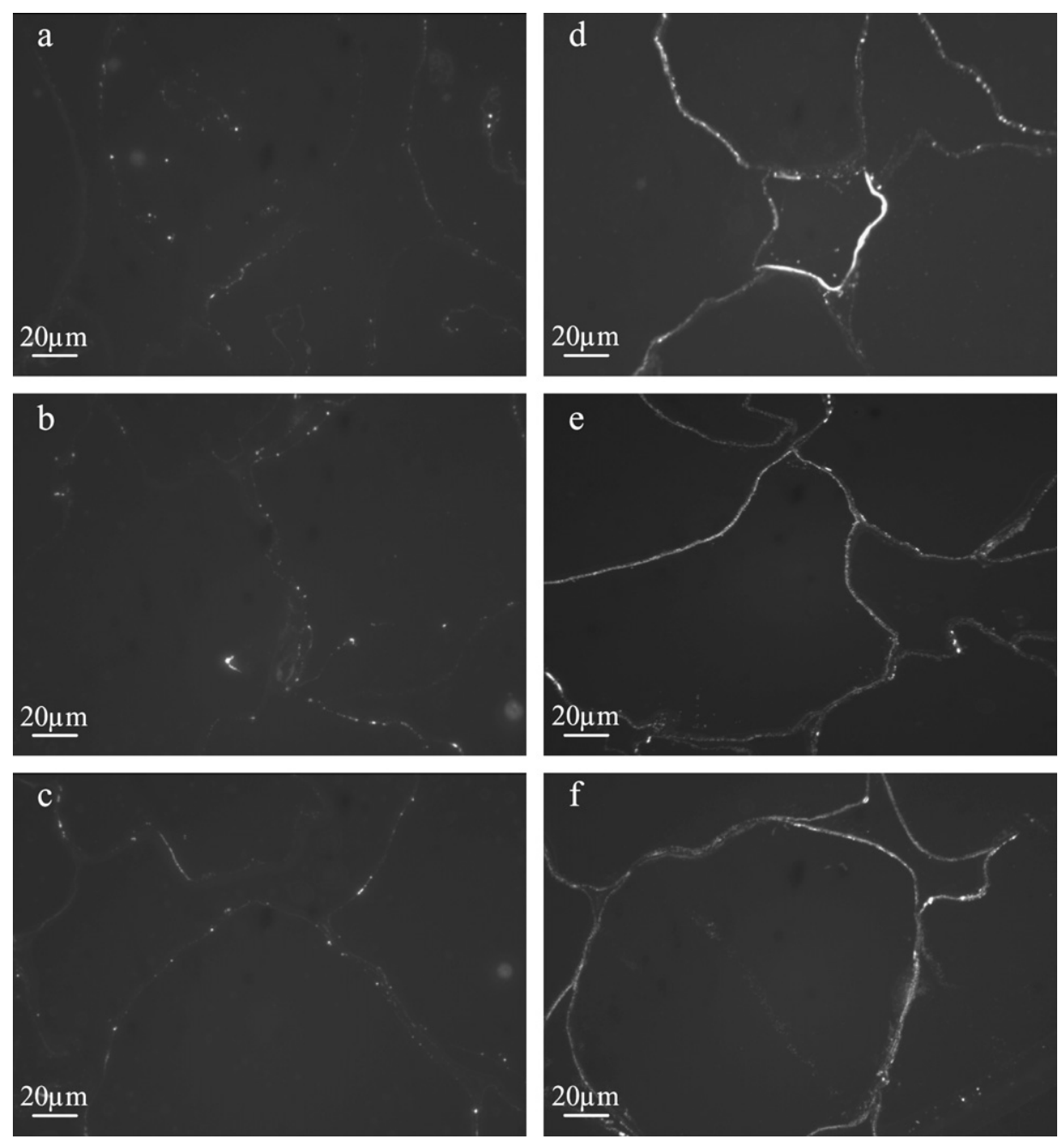

Fig. 4. Immunofluorescent labelling of PME with anti-A. niger PME antibodies in apple parenchyma tissue: PME vacuum-infused (d, e, f); water-infused control ( $\mathrm{a}, \mathrm{b}, \mathrm{c})$; superficial zone ( $0-2 \mathrm{~mm}$ depth) of apple tissue cubes $(\mathrm{a}, \mathrm{d})$; intermediate zone (2-4 mm depth) (b, e), core zone (more than $4 \mathrm{~mm}$ depth in apple cubes) (c, f).

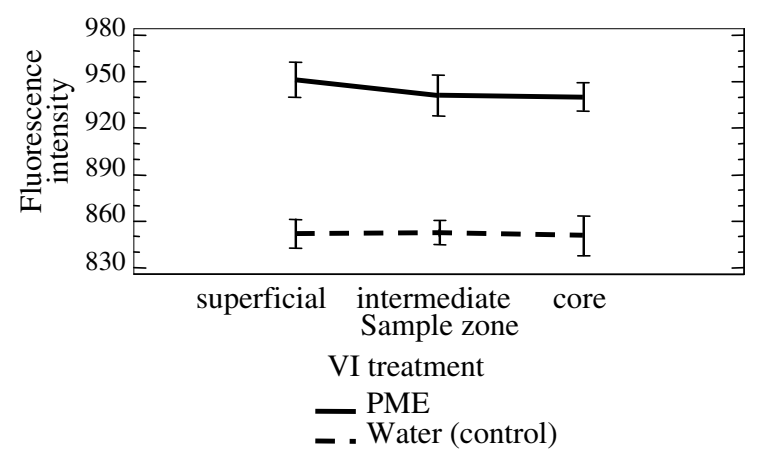

Fig. 5. Mean immunofluorescence PME labelling intensity measured in the different zones of apple cubes vacuum-infused either only with water (control) or with PME (PME).

subsequently pasteurized after $20 \mathrm{~min}$ of incubation at $40^{\circ} \mathrm{C}$ to activate exogenous PME are shown in Table 1. The control apple sample presented a high degree of methyl-esterification as it is usually encountered for apple (Renard, 1989). A second control was necessary, since the
Table 1

Methyl-esterification degree of pectins in non-impregnated, vacuumimpregnated with water or with a 450 nkat $\mathrm{PME} \mathrm{g}^{-1}$ solution apple cubes

\begin{tabular}{llll}
\hline Samples & $\begin{array}{l}\text { Non- } \\
\text { impregnated } \\
\text { apple cubes }\end{array}$ & $\begin{array}{l}\text { Water vacuum- } \\
\text { impregnated } \\
\text { apple cubes }\end{array}$ & $\begin{array}{l}\text { PME vacuum- } \\
\text { impregnated } \\
\text { apple cubes }\end{array}$ \\
\hline $\begin{array}{c}\text { Pectins degree of } \\
\text { methyl-esterification } \\
(\%)\end{array}$ & $80.5( \pm 2.3)$ & $82.2( \pm 2.6)$ & $45.1( \pm 2.3)$ \\
\hline
\end{tabular}

The two last samples were thermally treated for PME activation $\left(40^{\circ} \mathrm{C}\right.$, $20 \mathrm{~min})$ and subsequently pasteurized $\left(85^{\circ} \mathrm{C}, 15 \mathrm{~min}\right)$.

20 min incubation at $40^{\circ} \mathrm{C}$, that was initially performed to activate exogenous PME, could also activate endogenous apple PME. The degree of methyl-esterification after this incubation was not modified $(80.5 \pm 2.3 \%)$. The degree of methyl-esterification of pectins in apple cubes impregnated with PME was reduced to $45.1( \pm 2.2 \%)$.

Considering the amount of added enzyme, this decrease in degree of methyl-esterification corresponded to about 
$10 \%$ of the $A$. niger PME activity measured under optimal conditions (in a $1 \%(\mathrm{w} / \mathrm{w})$ highly methoxylated pectin solution maintained at a $\mathrm{pH}$ value 4.5). Since Duvetter et al. (2005) demonstrated the absence of fungal PME inhibitor in apple, this low activity for vacuum-infiltrated PME can result from two factors:

(i) The environment of the enzyme is not optimal in the fruit: the $\mathrm{pH}$ measured in apple tissue is more acidic
(3.2) than the optimal $\mathrm{pH}$ for the $A$. niger $\mathrm{PME}$ activity (4.5). For a $1 \%(\mathrm{w} / \mathrm{w})$ pectin in $0.1 \mathrm{M} \mathrm{NaCl}$ solution, the activity at $\mathrm{pH} 3.2$ is reduced about $75 \%$ compared with the activity at $\mathrm{pH} 4.5$. The ionic environment and particularly the calcium concentration may also affect PME activity (Jensen, Petersen, \& Adler-Nissen, 2004).

(ii) The PME activity in a heterogeneous system may differ: Tajchakavit and Ramaswamy (1997) have
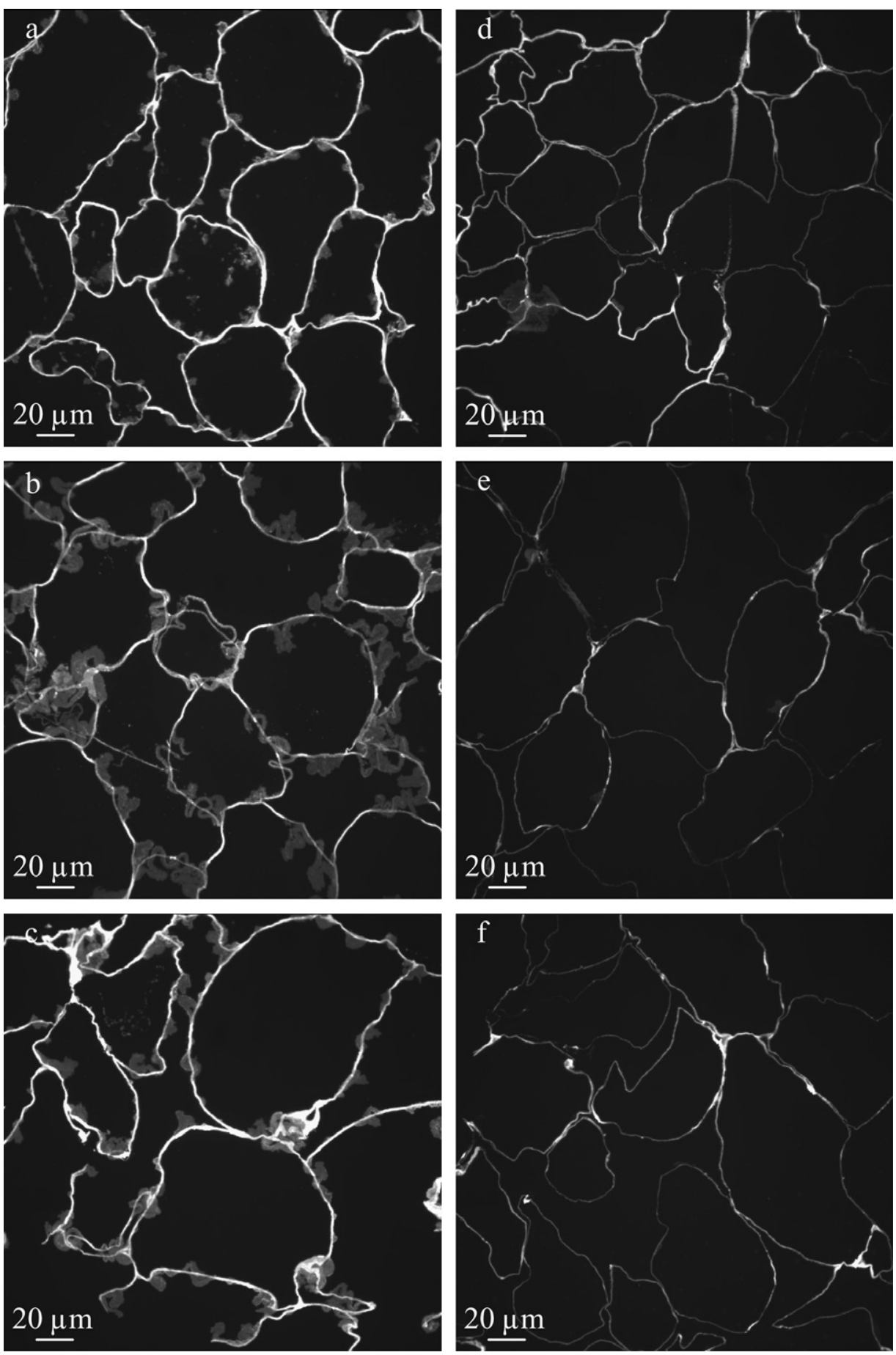

Fig. 6. Immunofluorescence labelling of methyl-esterified homogalacturonan with JIM7 in apple parenchyma tissue: PME vacuum-infused (d, e, f); waterinfused control ( $\mathrm{a}, \mathrm{b}, \mathrm{c})$; superficial zone $(0-2 \mathrm{~mm}$ depth) of apple tissue cubes $(\mathrm{a}, \mathrm{d})$; intermediate zone $(2-4 \mathrm{~mm}$ depth) $(\mathrm{b}$, e), core zone (more than $4 \mathrm{~mm}$ depth in apple cubes) (c, f). 
demonstrated that the activities of added PME in a fruit juice and in a fruit puree differed. Furthermore, compartmentation of apple tissue might limit the contact of PME with its substrate.

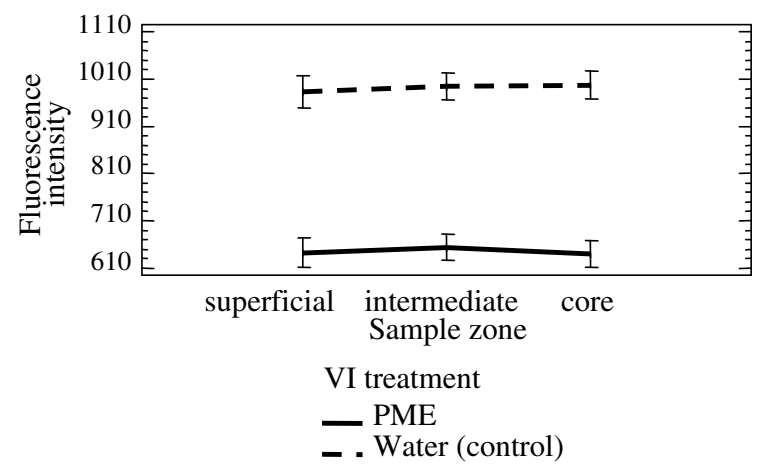

Fig. 7. Mean immunofluorescence labelling intensity with JIM7 measured in the different zones of apple cubes vacuum-infused with either only water (control) or with PME (PME).
JIM7 monoclonal antibodies were employed to examine the distribution of methyl-esterified residues with adjacent or flanking unesterified galacturonic acid (GalA) residues (Clausen et al., 2003) (Figs. 6 and 8).

At the tissue and cell levels (light microscopy), water infused samples, used as controls, showed an important and homogeneous fluorescence resulting from JIM7 antibodies binding in all the slices that are collected at different depths in apple cubes (Fig. 6a-c). By contrast, PMEinfused samples showed fewer homogeneous fluorescent patches in all observed zones (Fig. 6d-f). PME induces the hydrolysis of methyl esters on pectin and the vacuumimpregnation results in a homogenous pectin demethylesterification in the entire apple cubes. This qualitative observation is supported by a similar decrease in fluorescence intensity resulting from JIM7 antibodies binding in all zones, including the apple cube core (Fig. 7). Thereby, vacuum-impregnation constitutes a valuable process for placing an enzyme in contact with its substrate homogenously in the fruit tissue (Guillemin et al., 2006).
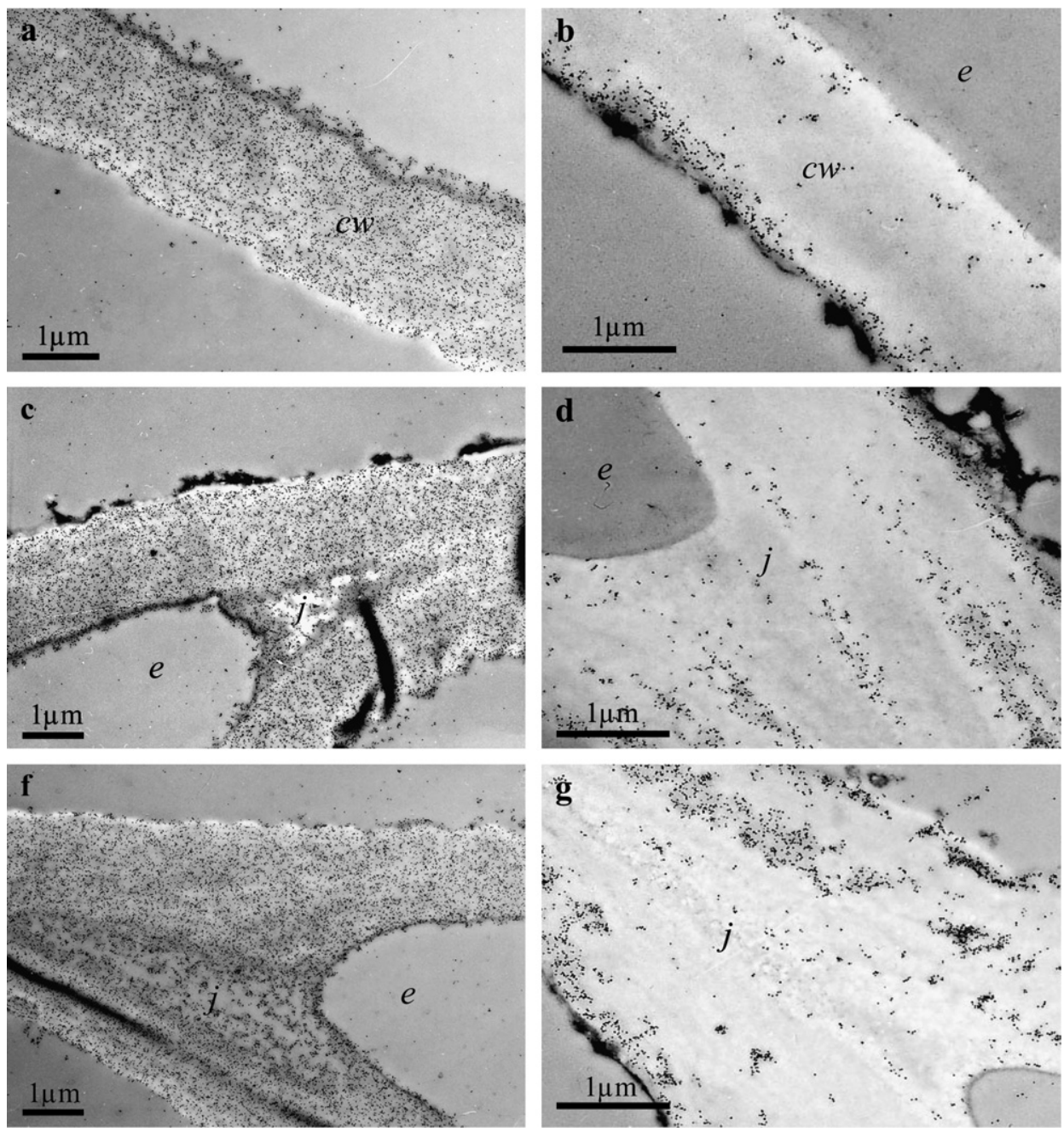

Fig. 8. Immunogold labelling of cell walls with JIM7 (methyl-esterified homogalacturonans) in apple cubes vacuum-infused only with water (a, $\mathrm{c}$ and $\mathrm{f}$ ) or with A. niger PME solution (b, d and g). (a) and (b) primary cell wall, (c) and (d) cell wall region lining intercellular space, (f) and (g) cell junction. $\mathrm{j}$ cell junction, cw cell wall, e intercellular space. 
The pattern of JIM7 labelling, that was observed by light microscopy, was confirmed at the ultrastructural level (Fig. 8). After water infusion, all cell walls were labelled across their width and entire length (Fig. 8a, c and f). For each zone, labelling decrease from cell to cell was observed after PME solution infusion (Fig. 8b, d and g) and the labelling density was not uniform across the wall length. Generally, labelling was less dense in regions lining intercellular spaces (Fig. 8b). Along the cell membrane, the labelling density decreased, but there was some fluorescent patch again in each observed zone (Fig. 8b and d). Moreover, a lot of fluorescent patches were observed in some apple core zones, namely around the meat.

To complete this analysis, the formation of unesterified galacturonic blocks consecutive to the PME activity was also checked at the cell wall level (electron microscopy; Fig. 9). For this purpose, sections were immunolabelled with the 2F4 monoclonal antibody-recognizing calciumdimerized oligogalacturonides of nine sugar residues (Liners et al., 1989, 1992). In water-infused samples (Fig. 9a, c and $\mathrm{f}$ ), the 2F4 epitope occurred mainly at tricellular junctions (Fig. 9f). In PME-infused samples, labelling was uneven from cell to cell (Fig 9b, d and g). It was generally more intense in cell wall regions lining intercellular space (Fig. 9d and g), suggesting the presence of channels facilitating the penetration of the exogenous PME solution into apple tissue during the vacuum-impregnation process. These results are in accordance with a previous study (Guillemin et al., 2006). This established that infused enzyme was located in the intercellular spaces and close to the plant cell wall and indicated that a channel provides a way for fluid movement and for rapid penetration of exogenous PME solution into apple tissue during the vacuum-impregnation process.

According to the decrease in pectin methyl-esterification and to the modification of pectin epitopes distribution in apple tissue and cell walls after PME infiltration, it is clear that the enzyme was active wherever found in the tissue. This result agrees with the Banjongsinsiri et al. (2004b) observations on $A$. niger PME vacuum-infused eggplant slices. Vacuum-impregnation resulted in a higher penetration and in a more homogeneous distribution of the
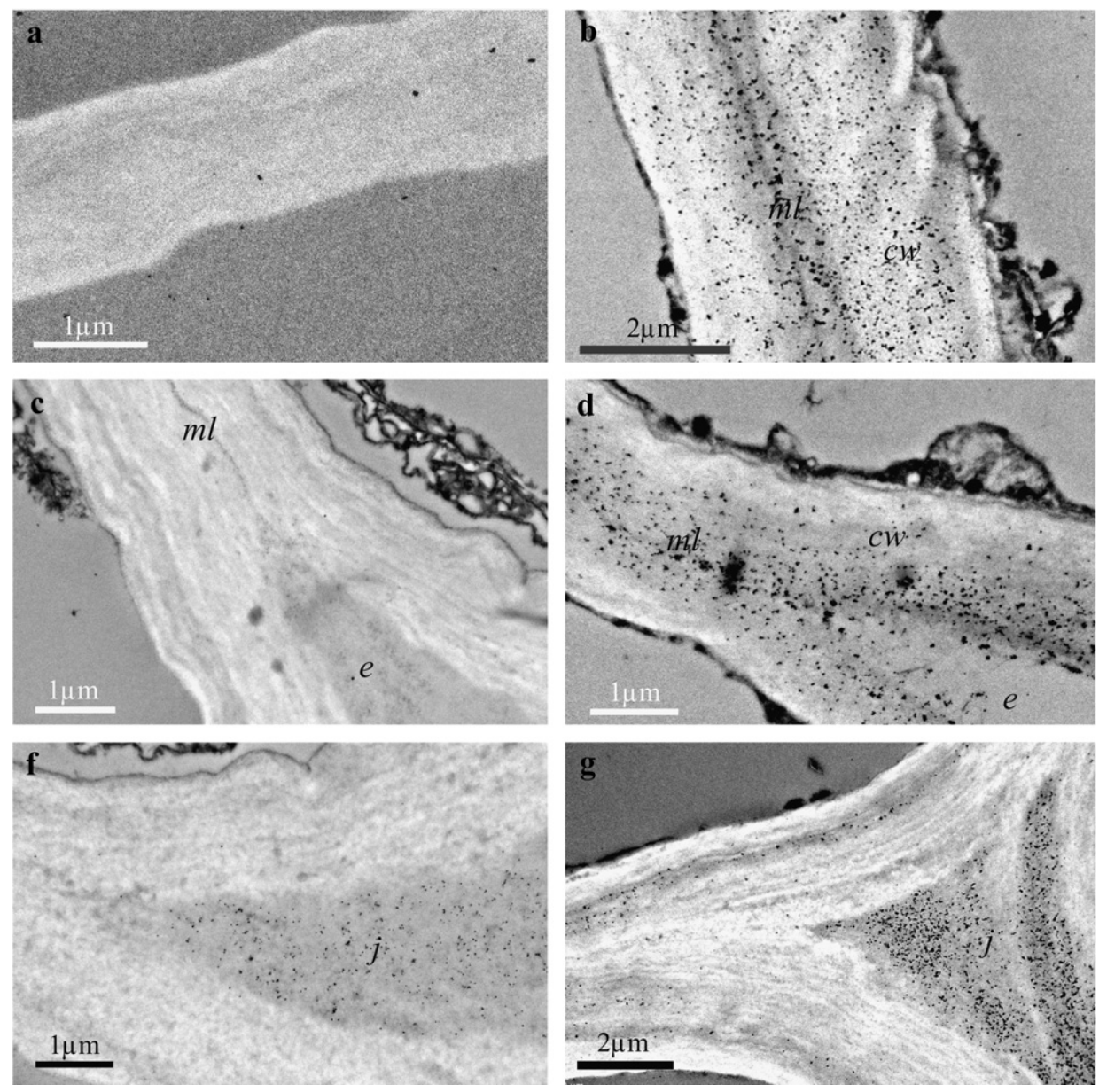

Fig. 9. Immunogold labelling of cell walls with $2 \mathrm{~F} 4$ (blocks of non-methyl-esterified galacturonic acid units) in apple cubes vacuum-infused only with water ( $\mathrm{a}, \mathrm{b}$ and $\mathrm{c}$ ) or with an A. niger PME solution ( $\mathrm{d}, \mathrm{f}$ and $\mathrm{g}$ ). $\mathrm{a}$ and $\mathrm{b}$ primary cell wall, $\mathrm{c}$ and $\mathrm{d}$ cell wall region lining intercellular space, e and $\mathrm{g}$ cell junction. 
enzyme in apple cubes. Nevertheless, some zones were not homogeneously impregnated (Fig. 9d). This is probably due to local micro-heterogeneity of apple tissue structure resulting in local differences of exogenous PME transfer.

Moreover, the immunolabelling patches were not homogeneously shared in the cell wall. Association between pectins and 2F4 can occur only if the local degree of methyl-esterification is less than $30 \%$, necessarily implying the presence of blocks of free carboxyl groups (Liners et al., 1992). This study indicates that, although the mean degree of methyl-esterification of pectins is $45 \%$, some homogalacturonan zones along pectin chains present a lower degree of methyl-esterification, even if fungal PME is employed. This is more notable if we keep in mind that fungal PMEs have a mechanism of demethyl-esterification regarded as random, resulting in the de-esterification of single GalA residues per enzyme/substrate interaction (a multiple chain mechanism) (Duvetter et al., 2006).

\section{Conclusions}

The vacuum-impregnation process of pectin methylesterase made for a deep and homogeneous distribution of the enzyme in apple cubes (Guillemin et al., 2006). PME and calcium infiltration resulted in a firming effect. The mechanism of tissue failure, in relation to the experimental measurements, is linked to the structure and to the microstructure of the tissue. Since pectin plays a key role in apple tissue firmness, the impact of the infiltrated PME on the chemistry of homogalacturonan zones of pectin in apple tissue was assessed.

The degree of methyl-esterification of pectins in apple which was impregnated with PME decreased significantly (from $80 \%$ to $45 \%$ ). Immunolabelling of apple tissue, with antibodies binding to methyl-esterified residues with adjacent unesterified residues along homogalacturonan zones of pectin (JIM 7) and with antibodies recognizing calcium-dimerized oligogalacturonides of nine sugar residues (2F4), confirmed the action of PME along pectin chains and demonstrated, for the first time, that demethyl-esterified pectin zones associate with calcium.

In order to assess the heterogeneity of methyl-esterification along homogalacturonan zones of pectin, the specific demethyl-esterification mechanism (random) of fungal PME gives good reason for performing specific inspections. In particular, microscopic observations with specific antibodies for various epitopes along pectin chains should be carried out in addition to the determination of their degree of methyl-esterification by a chemical method and to the study of the enzyme diffusion in the apple tissue.

Since plant PMEs have a single chain mechanism resulting in the formation of consecutive demethyl-esterified GalA residues (Willats et al., 2001), it would be interesting to follow their impregnation in order to assess whether the pattern of methyl-esterification of pectin and the structural modification of plant tissue are different, or not.

\section{Acknowledgements}

This research was supported by the La Région RhôneAlpes (Ph.D. grant of Anne Guillemin and "Avenir" contract). The authors thank T. Chevalier and J. Vigouroux (INRA-BIA) for technical assistance. TEM and confocal microscopy observations and solid state NMR experiments were performed at the Biopolymers Interactions-Structural Biology platform (RIO-BIBS, UR 1268 BIA INRA Nantes).

\section{References}

Banjongsinsiri, P., Kenney, J., \& Wicker, L. (2004a). Detection of vacuum infusion of pectinmethylesterase in strawberry by activity staining. Journal of Food Science, 69, 179-183.

Banjongsinsiri, P., Shields, J., \& Wicker, L. (2004b). Vacuum infusion of plant or fungal pectinmethylesterase and calcium affects the texture and structure of eggplants. Journal of Agricultural and Food Chemistry, $52,8214-8223$.

Blumenkrantz, N., \& Asboe-Hansen, G. (1973). New method for quantitative determination of uronic acids. Analytical Biochemistry, 54, 484-489.

Clausen, M. H., Willats, W. G. T., \& Knox, J. P. (2003). Synthetic methyl hexagalacturonate hapten inhibitors of anti-homogalacturonan monoclonal antibodies LM7, JIM5 and JIM7. Carbohydrate Research, 338, 1797-1800.

Degraeve, P., Saurel, R., \& Coutel, Y. (2003). Vacuum impregnation pretreatment with pectinmethylesterase to improve firmness of pasteurized fruits. Journal of Food Science, 68(2), 716-721.

Duvetter, T., Van Loey, A., Smout, C., Verlent, I., Ly Nguyeng, B., \& Hendrickx, M. (2005). Aspergillus aculaetus pectin methylesterase: study of the inactivation by temperature and pressure and the inhibition by pectin methylesterase inhibitor. Enzyme and Microbial Technology, 36, 385-390.

Duvetter, T., Fraeye, I., Sila, D. N., Verlent, I., Smout, C., Hendrickx, M., et al. (2006). Mode of de-esterification of alkaline and acidic pectin methyl esterases at different $\mathrm{pH}$ conditions. Journal of Agricultural and Food Chemistry, 54(20), 7825-7831.

Fito, P., \& Pastor, R. (1994). Non-diffusional mechanisms occurring during vacuum osmotic dehydration. Journal of Food Engineering, 21, 513-519.

Fito, P., Andres, A., Chiralt, A., \& Pardo, P. (1996). Coupling of hydrodynamic mechanism and deformation-relaxation phenomena during vacuum treatments in solid porous food-liquid systems. Journal of Food Engineering, 27, 229-240.

Grant, G. T., Morris, E. R., Rees, D. A., Smith, P. J. C., \& Thom, D. (1973). Biological interactions between polysaccharides and divalent cations: the egg-box model. FEBS Letters, 32, 195-198.

Guillemin, A., Degraeve, P., Guillon, F., Lahaye, M., \& Saurel, R. (2006). Incorporation of pectinmethylesterase in apple tissue either by soaking or by vacuum impregnation. Enzyme and Microbial Technology, 38, 610-616.

Guillemin, F., Guillon, F., Bonnin, E., Devaux, M. F., Chevalier, T., Knox, J. P., et al. (2005). Distribution of pectic epitopes in cell walls of the sugar beet root. Planta, 222, 355-371.

Jarvis, M. C., Briggs, S. P. H., \& Knox, J. P. (2003). Intercellular adhesion and cell separation in plants. Plant, Cell and Environment, 26, 977-989.

Javeri, H., Toledo, R., \& Wicker, L. (1991). Vacuum infusion of citrus pectinmethylesterase and calcium effects on firmness of peaches. Journal of Food Science, 56(3), 739-742.

Jensen, M., Petersen, B. R., \& Adler-Nissen, J. (2004). Enzymatic firming of processed red pepper by means of exogenous pectinesterase. Food Biotechnology, 18(2), 217-227. 
Kunzek, H., Kabbert, R., \& Gloyna, D. (1999). Aspects of material science in food processing: changes in plant cell walls of fruits and vegetables. Zeitschrift für Lebensmittel Untersuchung und Forschung, 56(3), 739-742.

Levigne, S., Thomas, M., Ralet, M. C., Quemener, B., \& Thibault, J. F. (2002). Determination of the degrees of methylation and acethylation of pectins using C18 column internal standards. Food Hydrocolloids, 16(6), 547-550.

Liners, F., Letesson, J. J., Didembourg, C., \& Van Cutsem, P. (1989). Monoclonal antibodies against pectin. Recognition of a conformation induced by calcium. Plant Physiology, 94, 1419-1424.

Liners, F., Thibault, J. F., \& Van Cutsem, P. (1992). Influence of the degree of polymerization of oligogalacturonates and of esterification pattern of pectin on their recognition by monoclonal antibodies. Plant Physiology, 99, 1099-1104.

Matringe, E., Chatellier, J., \& Saurel, R. (1999). Improvement of processed fruit and vegetable texture by using a new technology "vacuum infusion". In Proceedings of the international congress "Improved traditional foods for the next century", October 28-29, Valencia, Spain (pp. 164-167).

Nieto, A. B., Salvatori, D. M., Castro, M. A., \& Almazora, S. M. (2004). Structural changes in apple tissue during glucose and sucrose osmotic dehydration: shrinkage, porosity, density and microscopic features. Journal of Food Engineering, 61, 269-278.

Renard, C. M. G. C. (1989). Etude des polysaccharides pariétaux de la pomme: Extraction et caractérisation par des méthodes chimiques et enzymatiques. Thèse de troisième cycle présentée à l'Université de Nantes.
Ridley, B. L., O'Neil, M. A., \& Mohnen, D. (2001). Pectins: structure biosynthesis and oligogalacturonide related signalling. Phytochemistry, $57,929-967$.

Saurel, R. (2004). Improving the texture of processed vegetables by vacuum infusion. Texture in Food (pp. 364-387). D. Kilcast, Woodhead, Cambrige.

Suutarinen, J., Honkapää, K., Heiniö, R. L., Autio, K., \& Mokkila, M. (2000). The effect of different prefreezing treatments on the structure of strawberries before and after jam making. Lebensmittel Wissenschaft und Technologie, 33, 188-201.

Tajchakavit, S., \& Ramaswamy, H. S. (1997). Thermal vs. microwave inactivation kinetics of pectin methylesterase in orange juice under batch mode heating conditions. Lebensmittel Wissenschaft und Technologie, 30, 85-93.

Thibault, J. F. (1979). Automatisation du dosage des substances pectiques par la méthode au métahydroxydiphényl. Lebensmittel Wissenschaft und Technologie, 12, 247-251.

Voragen, A. C. J., Pilnik, W., Thibault, J.-F., Axelos, M. A. V., \& Renard, C. M. G. C. (1995). Pectins. In A. M. Stephen \& Y. Dea (Eds.). Food polysaccharides (Vol. 10, pp. 287-339). Londres, United Kingdom: Marcel Dekker.

Willats, W. G. T., Orfila, C., Limberg, G., Buchholt, H. C., Van Alebeek, G. J., Voragen, G. J., et al. (2001). Modulation of the degree and pattern of methyl-esterification of pectic homogalacturonan in plant cell walls. Implications for pectinmethylesterase action, matrix properties and cell adhesion. The Journal of Biological Chemistry, 276, 19404-19413. 